
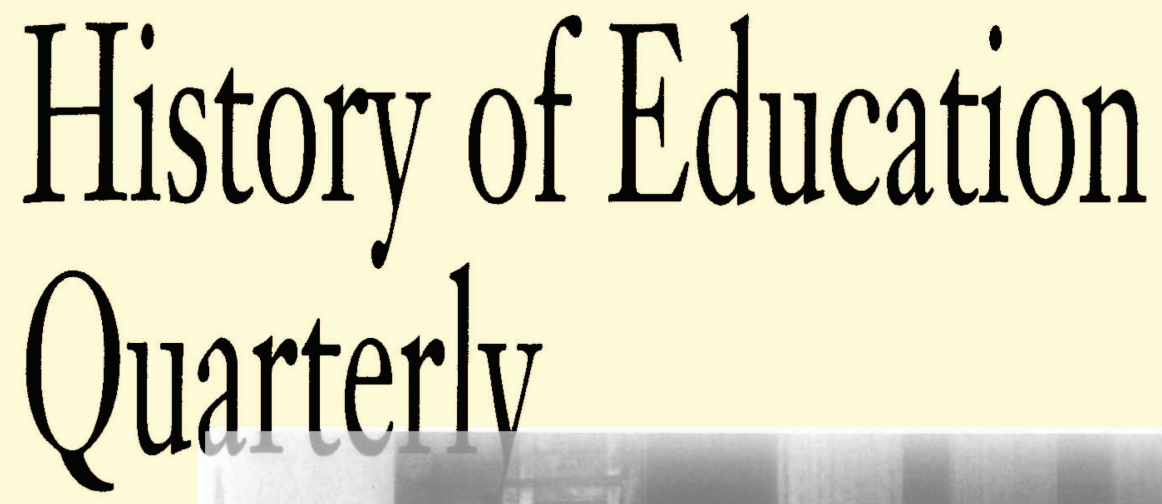

\title{
Summer 2000
}

Volume 40, Number 2 


\title{
History of Education Society
}

The History of Education Society is an international scholarly society. Its purposes are to encourage and facilitate research in the history of education; to promote and improve the teaching of history of education; to encourage cooperation among specialists in history of education; and to promote an appreciation of the value of historical perspective in the making of educational policy. The Society is affiliated with the International Standing Conference for the History of Education, and members of the Society are automatically members of the Standing Conference.

\section{Officers (2000)}

President
Vice-President
Secretary-Treasurer
Directors

\author{
WILLIAM J. REESE, University of Wisconsin, Madison \\ RONALD BUTCHART, University of Georgia \\ C.H. EDSON, University of Oregon, 1996-1999 \\ BARBARA FINKELSTEIN, (Past President) University \\ of Maryland \\ ROBERTA WOLLONS, Indiana University Nortbwest, \\ 1998-00 \\ KATE ROUSMANIERE, Miami University (Obio), \\ 1999-01 \\ MARCIA G. SYNNOTT, University of South Carolina, \\ 2000-02
}

THE CLAUDE C. EGGERTSEN DISSERTATION PRIZE: This $\$ 1000$ prize will be awarded for the most outstanding dissertation in the History of Education completed in the previous year. The prize will be first awarded at the Society's annual meeting in 2000.

Inquiries should be directed to Professor Roberta Wollons, Department of History, Indiana University Northwest, 3400 Broadway, Gary, Indiana 46408.

THE HISTORY OF EDUCATION SOCIETY AWARD: This award of $\$ 500$ will be made biennially to the best essay in the history of education published in any journal over the previous two years. The next award will be presented at the fall 2000 meeting of the History of Education Society. Any article published in 1998 or 1999 will be eligible for the award.

THE HENRY BARNARD PRIZE: This prize of \$500 is awarded biennially to the best essay in the history of education by a graduate student. The next award will be presented at the fall 2001 meeting of the History of Education Society. The recipient will have the essay published in the History of Education Quarterly.

Inquiries regarding these two awards should be directed to the chairperson of the Prize Committee: Professor Jonathan Zimmerman, Department of Humanities and Social Sciences, School of Education, New York University, New York, New York 10003.

OUTSTANDING BOOK AWARD: This award of \$500 is made biennially to the author of the best book on the history of education published in the two previous years. The committee will accept nominations but will also make every effort to review all relevant works, whether or not they have been nominated. The award for books bearing 1999 and 2000 publication dates will be announced at the annual meeting of the Society in 2001 .

Inquiries regarding the Outstanding Book Award should be directed to the chairperson: Professor Daniel Perlstein, 3525 Tolman Hall, Graduate School of Education, University of California, Berkeley, CA 94720-1670.

The Society reserves the right not to make awards in those years when the Prize Committee judges all entries to be of insufficient quality. 


\section{History of Education Quarterly}

\section{Editorial Staff}

Editor

Associate Editors

Managing Editor

Editorial Assistant

Editorial Assistant
RICHARD J. ALTENBAUGH, Slippery Rock University BARBARA BEATTY, Wellesley College LINDA EISENMANN, University of Massachusetts, Boston

MiCHAEL FUlTZ, University of Wisconsin, Madison ROBERT A. LEVIN, Youngstown State University BRUCE C. NELSON PHYLLIS KENDZIORSKI GARY L. COLE, JR.

\section{Editorial Board}

KathleEN Alaimo, Saint Xavier University

Clinton B. Allison, University of Tennessee, Knoxville

KATE CRUIKSHANK, Indiana University

WILliam CUTLER, III, Temple University

DAVID D. DIXON, Slippery Rock University

ERNEST FREEBERG, Colby-Sawyer College

PHILIP GARDNER, University of Cambridge

CRAIG KRIDEL, University of South Carolina

MICHAEL MURPHY, University of Western Ontario

TOM O'DONOGHUE, University of Western Australia

CHRISTINE A. OGREN, University of Iowa

PATRICIA PALMIERI, University of Michigan

DANIEL PERLSTEIN, University of California, Berkeley

DAVID R. ROEDIGER, University of Minnesota

Kate Rousmaniere, Miami University (Obio)

SUSAN SEMEL, Hofstra University

ROBERT R. SHERMAN, University of Florida

FRANK SIMON, University of Ghent

VANESSA SIDDLE WALKER, Emory University

ROBERTA WOLLONS, Indiana University Nortbwest

The History of Education Quarterly (ISSN 00 182680) is published Spring, Summer, Fall, and Winter by the History of Education Society in conjunction with the College of Education, Slippery Rock University, Slippery Rock, PA 16057-1326. Membership in the Society, which includes subscription to the Quarterly, is available at the following rates: students, $\$ 20$; others, $\$ 40$ (non-U.S. members add $\$ 7$ to cover additional postage, surface mail; $\$ 20$ for overseas airmail). Institutional subscription rates are: $\$ 77$, U.S.; $\$ 84$, non-U.S. All payment must be made in U.S. dollars. Single copies of some back issues are available at $\$ 10$ plus postage. Periodicals postage paid at Slippery Rock, PA and other offices. POSTMASTER: Send address changes to History of Education Quarterly, College of Education, Slippery Rock University, Slippery Rock, PA 16057-1326.

The Quarterly can be contacted:

by mail at

by phone at

by FAX

by e-mail

and on the World Wide Web at http://wwe.sru.edu/depts/scthes/hes.htm

Ilistory of Eduation Quaterly Vol. 40 No. 2 Summer 2000

Copyright 2000 by the llistory of Fducation Socicty 


\section{History of Education Society}

INDIVIDUAL MEMBERSHIP: Membership is open to all persons interested in the study of the history of education. Membership provides for subscription to the History of Education Quarterly; subscription to Network, a newsletter published jointly with Division F of the American Educational Research Association; and receipt of the program of the annual meeting of the Society. Members of the Society are automatically members of the International Standing Conference for the History of Education. Membership offers subscription to publications on a calendar-year basis only. Dues are $\$ 20$ for students, $\$ 40$ for others. Non-U.S. members should add $\$ 7$ to cover additional postage for surface mail; $\$ 20$ for airmail. The portions of dues designated for support of the Quarterly are $\$ 20$ of student dues, $\$ 32$ of other individual dues. To become a member, send a check for the appropriate amount in U.S. dollars only to the History of Education Quarterly, College of Education, Slippery Rock University, Slippery Rock, PA 16057-1326. Make checks payable to History of Education Society. Indicate preferred mailing address and the calendar year in which your subscription should begin.

\section{History of Education Quarterly}

INSTITUTIONAL SUBSCRIPTIONS: Institutions may subscribe to the History of Education Quarterly directly (send checks to History of Education Quarterly, College of Education, Slippery Rock University, Slippery Rock, PA 16057-1326) or through subscription agencies. Rates are \$77, U.S.; \$84, non-U.S., U.S. dollars only.

BACK ISSUES: Some back issues are available (cost $\$ 10$ per issue plus postage).

INDEXES: Three indexes are available: Index to Vols. I-X (1961-1970), by Murray S. Shereshewsky (\$5); Index to Vols. XI-XX (1971-1980), by Paul Mattingly and Marilyn Tobias (\$7); and Index to Vols. XXI-XXX (1981-1990), by Gary L. Bailey (\$14 to HES members and $\$ 20$ to others).

ARTICLE SUBMISSIONS: Contributions should be addressed to: Editor, History of Education Quarterly, College of Education, Slippery Rock University, Slippery Rock, PA 16057 1326. See last page of this issue for guidelines on submission. The editor will only consider articles that have been submitted exclusively to the History of Education Quarterly.

BOOK REVIEWS: Assignments of reviews are made from a file of potential reviewers. To have your name added to the file, send curriculum vitae to the editor. Requests to review particular books cannot be honored.

The History of Education Quarterly is printed by Indiana University Printing Services.

The History of Education Quarterly is located at, but independent of, Slippery Rock University. 


\section{History \\ of Education \\ Quarterly}

Volume 40 • Number 2 • Summer 2000

\section{Contents}

\section{Articles}

123

"A Good and Delicious Country": Free Children of Color and How they Learned to Imagine the Atlantic World in Nineteenth-Century Louisiana

Mary Niall Mitchell

145 Nation-State versus National Identity: State and Inspectorate in Mid-Victorian Wales

H.G. Williams

"Scholar," "Lady," "Best Man in the English Department"? Recalling the Career of Marjorie Hope Nicolson Andrea Walton

\section{Essay Review}

201 The Complex Historiography of Childhood: Categorizing Different, Dependent, and Ideal Children Barbara Beatty

\section{Book Reviews}

$220 \quad$ Woolfson, Padua and the Tudors

By Amy Thompson McCandless

222 Cobban, English University Life in the Middle Ages

By Anthony A. Koyzis

223 Vinovskis, History and Educational Policymaking By Harvey Kantor

226 Angus and Mirel, The Failed Promise of the American High School By William Wraga 
Farrar, A Creed for My Profession

By Lawrence B. Fuller

231

Hess, Spinning Wheels

By Don T. Martin

233

Michel, Children's Interests/Mothers' Rights

By Joseph Hawes

235 Tomes, Apocalypse Then

By William J. Rorabaugh

237 Roche, Restructured Resistance

By Wayne Urban

$239 \quad$ Hall, In the Vineyard

By Sarah C. Thuesen

241 Cuban, How Scholars Trumped Teachers

By Irving G. Hendrick

243 Bethell, Harvard Observed

By David Potts

245 Bordin, Women at Michigan

By Janice M. Leone

247 Melzer, Democracy and the Arts

By James F. Adomanis

250

Advertisement

251

Membership Application

252

Guidelines for Submissions

253

Call for Papers 